American Journal of Applied Sciences 9 (3): 417-424, 2012

ISSN 1546-9239

(C) 2012 Science Publications

\title{
Organizational Culture and Tourist Satisfaction in a Lake-Based Tourism Area
}

\author{
Nor' Aini Yusof, Mohd Fitri Che Jamil, \\ Ilias Said and Abdel Naser Omran Ali \\ School of Housing, Building and Planning, \\ University Sains Malaysia, 11800 Penang, Malaysia
}

\begin{abstract}
Problem statement: Although many studies have highlighted that certain cultures are evident in certain firms, there are only few studies done on ecotourism areas and little has been done to analyse how these cultures have affected the performance of these organizations. Approach: Conceptualizing organizational culture as the values and practices employed in an organization and considering tourist satisfaction as intangible performance we conducted a survey of all tourist resort operators located in a lake-based tourism area in Malaysia. The data wes analysed using descriptive statistics, paired ttest and Pearson product-moment correlation. Results: The results revealed that tourists are dissatisfied with the quality of service delivered to them and tourist satisfaction is significantly influenced by environmental friendly practices. Conclusion/Recommendations: The results imply that environmental friendly practices ranging from the issue of recycling, being compatible with local environment and culture and making minimal changes to the existing landform, should be the focus of the strategic policy in the future, to improve the planning and management of the resorts and the area promoted for tourism.
\end{abstract}

Key words: Organizational culture, organizational value, organizational practice, intangible performance, tourist satisfaction

\section{INTRODUCTION}

In contrast to the increased contribution of the tourism industry to the economy (Nejad and Tularam, 2010), many ecotourism destinations suffer from the lack of visitors' travel (Chui, 2010). Some resorts even have to cease operations after facing several years of annual losses (Jamil et al., 2010). In these destinations, researchers argue that tourists are dissatisfied with the service delivery such as cleanliness (Chui, 2010), security and safety (Ahmad et al., 2010), inadequate facilities and infrastructure (Arabatzis and Grigoroudis, 2010). Following the recent interest in organizational culture among researchers, scholars equate this poor performance with the lack of good culture within the resort operators' business organization in delivering the tourism products and services (Erdogan and Tosun, 2009). Culture in an organization is considered as a belief, values and practices which form the characteristics of an organization (Chegini, 2010). Organizational culture, either in the form of values or practices, is argued to have significant influence on the performance and long-term effectiveness of organizations. Chegini (2010) for example, proposes that certain cultural styles can encourage the establishment of 'proper' values in an organization, which results in a successful organization. Similarly, Vargas- Vargas-Hernandez and Noruzi (2009) argue that there are a set of general cultural types that can boost organization performance and encourage growth. The examples of the good culture in the context of the tourism industry are the practice of human resource planning, job design, staff development, quality circle and wage systems which have positive impact on organization performance (Chand and Katou, 2007). Conversely, we can assume that the lack of good culture will result in poor performance.

Previous studies have established that certain cultures will have a positive effect on the organizational performance. Nevertheless, the relationship between organizational cultures of SMEs in the tourism industry and their performance has received little research interest. Not much is known on the influence of organizational culture specifically in SMEs on performance. Besides, there are conflicting views on what can be considered as a good culture. Firms that

Corresponding Author: Nor'Aini Yusof, School of Housing, Building and Planning, University Sains Malaysia, 11800 Penang, Malaysia Tel: +6046535235 
adopt a consultative culture that encourages the discussion and analysis of performance measures of organization members, are more likely to perform better (Franco and Bourne, 2003). On the other hand, performance orientation, humanitarianism and assertiveness culture are revealed to establish highly significant relationships with the organizational capability to innovate, one of the key indicators to performance, in big housing firms. In the context of the ecotourism industry where the majority of the businesses are small, organization performance is often considered to include the intangible performance such as tourists' satisfaction and employees' satisfaction. Chand and Katour (2007) identify humane orientation culture such as utilizing HRM systems which can boost performance. Nonetheless, their study focuses only on 5-star hotel practices and not SMEs. Through a series of interviews, Kyriakidou and Gore (2005) establish that collaboration, employee focus, knowledgesharing and team work are the key cultural characteristics in the best performing SMEs in the tourism industry. Unfortunately, their study does not empirically relate SME culture with performance and it does not address SMEs in lake-based tourism. More recently, Jamil et al. (2010) find that environmental practices are negatively correlated with SMEs' financial performance. Following Philips and Louvieris (2005), the authors acknowledge the limitation of considering financial as a performance indicator for SMEs because of the flaw in accountingbased performance indicators.

The above discussion shows that there is still a need to investigate the relationship between organizational culture of SME resort operators and their intangible performance; that is tourist satisfaction. The focus of the study will be on the SMEs which are involved in delivering tourism products and services in one lake-based tourism destination. This study will answer two major questions, namely what are the values and practices adopted by these SMEs and secondly, how do these cultures influence SMEs' intangible performance? As such, this study provides better understanding on the relationship between organizational culture and performance in the context of lake-based tourism destination. Specifically, it extends Hofstede's dimensions of organizational values and organizational practices to suit with the lake-based tourism context, where the majority of the operators are small in terms of size. The study takes a different approach from Jamil et al. (2010) study by considering intangible performance, where it takes a look at the tourist satisfaction, instead.
Organizational culture: Perhaps, the most well cited definition of organizational culture is by Schein (1990), who considers organizational culture as shared beliefs among organizational members, expressed through symbols, ceremonies and myths. In an organization, organizational culture exists in terms of values, attitudes and behavior patterns (Dennison, 1984) that bind members together (Wright, 1986).

Therefore, organizational culture can be considered to consist of the subconscious and manifestation levels (Martins and Terblanche, 2003). The subconscious level or organizational value refers to 'the way we think about things around here' (Williams et al., 1993) and the manifestation level or organizational practice refers to 'the way we do things around here' (Williams et al., 1993). The detailed discussion of organizational values and practices is as follows.

Organizational values: Organizational values is a binding theme embedded in an organization which provides direction to members (Gardner, 1999). Hofstede (2003) introduces two dimensions of organizational value; the Power Distance Culture (PDC) and the Uncertainty Avoidance Culture (UAC). PDC is the culture in which members accept and endorse the dissemination of authority, power and status (House, 2004), while UAC is the culture whereby members feel threatened by uncertain situations (Hofstede and Bond, 1984) and try to curtail such situations by introducing stringent rules and regulations (Hofstede, 2003). Businesses in Malaysia generally adopt UAC; they are low risk takers (Yusof and Shafiei, 2011) and are only partially ready to change the way they run their business.

In addition, House (2004) introduce three dimensions of organizational value; performance orientation, humane orientation and assertiveness. Performance orientation is a culture which focuses on performance improvement and excellence and members are rewarded if they achieve high performance (Hofstede and Bond, 1984). Humane orientation, is a culture where members are encouraged and rewarded for being honest, unselfish, friendly and kindhearted (Hofstede and Bond, 1984), whereas assertiveness is a culture which members are challenging, provoking and become naturally uncompromising in their relationships with others (Hofstede and Bond, 1984). There is also the knowledge-sharing culture introduced by Kyriakidou and Gore (2005), which refers to a culture where members are encouraged to share the knowledge that they have acquired or created. 
Am. J. Applied Sci., 9 (3): 417-424, 2012

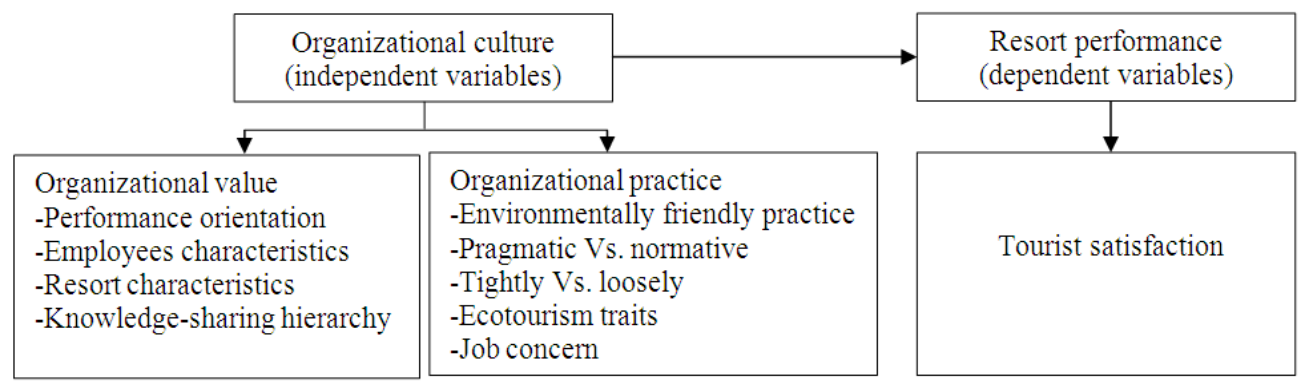

Fig. 1: Framework of the study

Organizational practices: This type of organizational culture is visible and can be observed from members' attitude, behavior and the language (Sathe, 1985). Hofstede et al. (2005) introduces three dimensions of organizational practices; job-oriented Vs. employeeoriented perspective, tight Vs. lose control and pragmatic vs. normative strategy. An organization that adopts job oriented practices places emphasis on employee's performance on carrying out their jobs and duties (Hofstede et al., 2005) and in contrast, employee-oriented practices focus on employee's wellbeing and job satisfaction (Blake and Mouton, 1964). Tight-control practices are cost, time and qualityconscious and have a high degree of formality whereas loose-control practices are flexible about costs, time and quality and, to loosely describe this, jokes about the company or job are frequent (Hofstede et al., 2005). Pragmatic vs. normative practices describe the degree to which the members deal with procedures and clients, or popularly known as customer orientation in management literature (Hofstede et al., 2005). Pragmatic practices strive for achieving results and fulfilling customers' needs than following procedures (Hofstede et al., 2005) whereas normative practices concentrate on complying with rules and procedures rather than achieving the results (Hofstede, 1998).

Besides, another dimension, known as Environmentally Friendly Practices (EFP) is also introduced following Kyriakidou and Gore (2005). EFP is the practices which consider their effect to the environment and the strategies used by the industry to address environmental problems.

Organizational performance: Scholars have conflicting views on the best indicator for organization performance. Tourism theorists acknowledge the use of tourist satisfaction as one of the main indicators for organization's performance. Eraqi (2006) for example, has suggested that the use of tourist perceptions and expectations of a product's or service's attributes can be a tool for determining the quality of the product or service provided. The issue of meeting the needs of the tourist is arguably cardinal for the survival of a business, regardless of its size. Seth et al. (2005) review models for evaluating service quality and conclude that a majority of models support the evaluation of service quality by comparing quality expectations with their perceptions of service quality received. Satisfied tourists and their decisions to return for a repeat visit are both influenced by a range of attributes (Kozak, 2001; Alegre and Cladera, 2006).

One of the most cited models for evaluating tourist satisfaction is the SERVQUAL model introduced by Parasuraman et al. (1988). The model consists of five dimensions of service quality; tangibility, reliability, responsiveness, assurance and empathy. Tangibility covers facilities, tools and workforce and communication materials. Reliability is regarded as the capability to carry out the services as pledged. Responsiveness is considered as the staff dedication to assist guests and deliver suitable service. Assurance means the understanding and courtesy of staff and their ability to establish trust and confidence. Lastly, empathy means being considerate and is thoughtful to every guest (Jamil et al., 2010). In addition, previous studies have included sustainability dimension as one of the key factors in tourism (Garcia-Falcon and MedinaMunoz, 1999; Brebbia and Pineda, 2010). Sustainability in tourism is considered as protecting the environment and local people, while fulfilling the objectives of the tourists and the industry (Dinan et al., 2000). Environmentally conscious tourists tend to demand for stricter environment protection and are willing to pay more money to enjoy the environment (Petrosillo et al., 2007). Therefore the original SERVQUAL model needs to be modified to include the sustainable dimension. Figure 1 presents the framework of this study. 
Am. J. Applied Sci., 9 (3): 417-424, 2012

\section{MATERIALS AND METHODS}

A face-to-face survey was conducted with resort employers, employees and tourists in Kenyir Lake, Terengganu. The questionnaires were divided into two parts. Part A which consists of two sections, was distributed to resort operators. The first section asks about the profile of the respondents. The second section is on organizational culture and the last section is concerned with resort profiles. The survey instrument used in the second section used a four-point scale ranging from 'strongly agree-(4)' to 'strongly disagree(1)' to indicate respondents' willingness or capacity to adopt the stated culture.

Part B aims to collect tourist satisfaction data, which consists of 12 items surrounding the general information of the respondents. Another section of the questionnaire concerns with tourists' expectations and experiences of products and services provided in Lake Kenyir. We employed the attributes used by Akama and Kieti (2003), who have modified the original SERVQUAL model and added four extra attributes referring to recycling, nature-based activities, change to the local environment and the use of local resources conceptualised as sustainable attributes, following $\mathrm{He}$ et al. (2008) and Khan (2003). In total, 27 items are used in this study to measure service quality. A four-point scale is used to ascertain tourists' expectations and experiences; (1) very dissatisfied, (2) dissatisfied, (3) satisfied and (4) very satisfied.

\section{RESULTS AND DISCUSSION}

Evaluations of organizational value and practice: In this study, a four-point scale (strongly agree-4 to strongly disagree-1) was used (Alegre and Cladera, 2006). Alston and Miller (2001) specification is utilized in interpreting the data; where 1.0-1.49 = Strongly Disagree, 1.5-2.49 = Disagree, 2.5-3.49 = Agree, 3.5$4.0=$ Strongly Agree. Table 1 presents the results.

From Table 1, it shows that the respondents strongly agree (mean $=3.54)$ that: "In this resort, managers should be encouraged to reward performance". The respondents also agree with all the other statements (means range from 2.5-3.49) except for "This resort emphasizes the traditional dress code", for which the mean is 2.25, indicating that the respondents disagree with the statement. Based on Table 1, we can also see that the dimensions of organizational value that are performance-oriented, have scored the highest compared to other dimensions, with 3.34 out of 4. This demonstrates that a performance-oriented culture exists at resorts that encourage innovativeness and put high consideration on performance. Additionally, these resorts also emphasize on good communication. Here, however, ecotourism traits have the lowest mean of 2.69 out of 4 . This indicates that employees are not active in expressing their opinion at the resorts.

Table 1: Descriptive statistics of dimensions and item

\begin{tabular}{|c|c|c|c|}
\hline Dimensions and Item & Mean & Std. Deviation & $\mathrm{N}$ \\
\hline \multicolumn{4}{|l|}{ Organizational value } \\
\hline Performance orientation & 3.34 & 0.508 & 51 \\
\hline At this resort, employees should be encouraged to be innovative & 3.38 & 0.602 & 51 \\
\hline At this resort, employees should be encouraged to strive for continuously improved performance & 3.36 & 0.663 & 51 \\
\hline At this resort, managers should be encouraged to reward performance & 3.54 & 0.579 & 51 \\
\hline At this resort, job requirements and instruction should be spelled out in detail & 3.38 & 0.667 & 51 \\
\hline At this resort, staff should be explicit and straightforward in communicating & 3.00 & 0.728 & 51 \\
\hline Employee Characteristics & 3.03 & 0.523 & 51 \\
\hline At this resort, staff should be very assertive (firm) & 2.92 & 0.724 & 51 \\
\hline I have a good relationship with my direct supervisor & 3.12 & 0.480 & 51 \\
\hline Resort Characteristics & 3.02 & 0.616 & 51 \\
\hline At this resort, there should be tolerance for breaking the rules or laws & 2.90 & 0.614 & 51 \\
\hline A resort structure should avoid certain employees having two bosses & 3.10 & 0.839 & 51 \\
\hline \multicolumn{4}{|l|}{ Organizational practice } \\
\hline Environmental practices & 3.18 & 0.496 & 51 \\
\hline I often share information regarding the ethics of this ecotourism area with visitors & 3.14 & 0.734 & 51 \\
\hline Our employees support environmental programs & 3.32 & 0.601 & 51 \\
\hline I often actively share my knowledge concerning work with my co-workers & 3.09 & 0.563 & 51 \\
\hline Pragmatic vs. Normative & 3.00 & 0.686 & 51 \\
\hline Quality always prevails over quantity in this resort. & 3.11 & 0.655 & 51 \\
\hline This resort emphasizes tasks related to satisfying customer needs more than procedures & 3.07 & 0.818 & 51 \\
\hline Ecotourism Traits & 2.69 & 0.583 & 51 \\
\hline This resort emphasizes traditional dress codes & 2.25 & 0.839 & 51 \\
\hline In this resort, I would express my opinion actively & 3.05 & 0.608 & 51 \\
\hline Job Concern & 2.83 & 0.486 & 51 \\
\hline The resort management is not concerned about the personal problems of its employees & 2.73 & 0.817 & 51 \\
\hline Everyone is cost-conscious here & 2.86 & 0.795 & 51 \\
\hline Resort performance & 41.17 & 12.063 & 51 \\
\hline
\end{tabular}


Am. J. Applied Sci., 9 (3): 417-424, 2012

Table 2: The overall score of service quality in Lake Kenyir

\begin{tabular}{|c|c|c|c|c|c|}
\hline Attributes & $\begin{array}{l}\text { Expectation } \\
\text { Mean (SD) }\end{array}$ & $\begin{array}{l}\text { Experience } \\
\text { Mean (SD) }\end{array}$ & Gap & $\mathrm{t}$-value & $\mathrm{p}$-value \\
\hline \multicolumn{6}{|l|}{ Sustainable } \\
\hline Visual attraction and the appeal of natural attractions. & $3.43(0.54)$ & $3.34(0.56)$ & -0.09 & 1.32 & 0.19 \\
\hline Non-crowded and unspoiled park & $3.39(0.66)$ & $3.30(0.65)$ & -0.09 & 1.39 & 0.17 \\
\hline Used natural/local resources as equipment and facilities. & $3.07(0.72)$ & $2.94(0.65)$ & -0.13 & 2.01 & 0.05 \\
\hline Emphasizing the importance for tourists to recycle and reuse product & $2.87(0.76)$ & $2.63(0.77)$ & -0.24 & 3.15 & $0.00 *$ \\
\hline Development integrated with local environment/culture & $3.05(0.61)$ & $2.89(0.66)$ & -0.16 & 2.40 & $0.02 *$ \\
\hline Nature-based activities (jungle tracking, kayaking/ bird watching) & $3.38(0.60)$ & $3.26(0.66)$ & -0.12 & 1.88 & 0.06 \\
\hline Minimal change to existing landform and vegetation & $3.08(0.68)$ & $2.88(0.65)$ & -0.20 & 3.39 & $0.00 * *$ \\
\hline \multirow{2}{*}{\multicolumn{6}{|c|}{ Tangible }} \\
\hline & & & & & \\
\hline $\begin{array}{l}\text { The physical facilities and equipment are } \\
\text { visually aligned and in good condition. }\end{array}$ & $3.07(0.63)$ & $2.88(0.63)$ & -0.19 & 2.47 & $0.02 *$ \\
\hline Information center gives relevant information. & $3.07(0.63)$ & $2.96(0.68)$ & -0.11 & 1.86 & 0.07 \\
\hline Adequate transport systems. & $3.11(0.68)$ & $2.78(0.76)$ & -0.33 & 4.53 & $0.00 * *$ \\
\hline Accessibility of physical facilities and natural resources & $3.06(0.58)$ & $2.92(0.62)$ & -0.14 & 2.15 & $0.03 *$ \\
\hline Neat appearance of the resort's staff & $2.95(0.65)$ & $2.82(0.69)$ & -0.13 & 1.91 & 0.06 \\
\hline Value for tangibility & $3.05(0.06)$ & $2.87(0.07)$ & -0.18 & 4.53 & $0.01 *$ \\
\hline \multicolumn{6}{|l|}{ Reliability } \\
\hline Staff giving prompt services & $3.06(0.59)$ & $2.87(0.71)$ & -0.19 & 2.83 & $0.01 *$ \\
\hline Staff providing service at the promised time. & $2.98(0.64)$ & $2.73(0.69)$ & -0.25 & 3.66 & $0.00 * *$ \\
\hline Staff providing accurate and correct information. & $3.09(0.57)$ & $2.86(0.58)$ & -0.23 & 4.00 & $0.00^{* *}$ \\
\hline Value for reliability & $3.04(0.06)$ & $2.82(0.08)$ & -0.22 & 12.66 & 0.06 \\
\hline \multicolumn{6}{|l|}{ Responsiveness } \\
\hline Willing to assist tourist & $3.19(0.58)$ & $3.05(0.62)$ & -0.14 & 2.60 & $0.01 *$ \\
\hline Staff never too busy to respond to tourist's question(s) & $3.18(0.65)$ & $3.00(0.67)$ & -0.18 & 3.04 & $0.00 * *$ \\
\hline Staff inform tourist of the exact services and products offered & $3.16(0.57)$ & $2.96(0.61)$ & -0.20 & 3.33 & $0.00 * *$ \\
\hline \multirow{2}{*}{\multicolumn{6}{|c|}{ Assurance }} \\
\hline & & & & & \\
\hline Tourist feels safe and secure. & $3.27(0.59)$ & $3.12(0.64)$ & -0.15 & 2.62 & $0.01 *$ \\
\hline Staff consistently courteous with tourist. & $3.21(0.56)$ & $3.11(0.61)$ & -0.10 & 1.61 & 0.11 \\
\hline Staff has the knowledge to answer questions. & $3.20(0.58)$ & $3.02(0.60)$ & -0.18 & 2.93 & $0.00 * *$ \\
\hline Adequate safety facilities. & $3.12(0.63)$ & $2.97(0.60)$ & -0.15 & 2.29 & $0.02 *$ \\
\hline Value for assurance & $3.20(0.06)$ & $3.06(0.07)$ & -0.14 & 8.74 & $0.03 *$ \\
\hline \multicolumn{6}{|l|}{ Empathy } \\
\hline Staff give the tourist personal attention. & $3.01(0.58)$ & $2.80(0.63)$ & -0.21 & 3.00 & $0.00 * *$ \\
\hline Staff understands the tourist's specific needs. & $3.10(0.62)$ & $2.94(0.65)$ & -0.16 & 2.40 & $0.02 *$ \\
\hline Convenient locations of facilities and equipment. & $3.21(0.59)$ & $3.01(0.66)$ & -0.20 & 3.33 & $0.00^{* *}$ \\
\hline Comfortable facilities & $3.14(0.62)$ & $2.98(0.66)$ & -0.16 & 2.09 & $0.04 *$ \\
\hline Adequate water supply & $3.19(0.62)$ & $3.10(0.69)$ & -0.09 & 1.39 & 0.17 \\
\hline Value for empathy & $3.13(0.08)$ & $2.96(0.11)$ & -0.17 & 7.77 & $0.01 *$ \\
\hline Overall value & $3.13(0.07)$ & $2.96(0.08)$ & -0.17 & 15.14 & $0.00 * *$ \\
\hline
\end{tabular}

A negative gap indicates that, the tourists' experiences have failed to live up to his or her expectations. A positive gap shows that the tourist's expectations have exceeded the tourist's experiences. The interpretation of the result was done at the $5 \%$ level of significance; *: p<0.05 was considered to be significant; $* *: \mathrm{p}<0.01$ was considered to be highly significant

Table 1 also shows that the cultural characteristics that are prevalent at the resorts are performance orientation $($ Mean $=3.34$ ), followed by environmental practices $($ Mean $=3.18)$, employee characteristics (Mean $=3.03)$, resort characteristics $($ Mean $=3.02)$, pragmatic Vs normative $($ Mean $=3.00)$, job concern $($ Mean $=2.83)$ and lastly, ecotourism traits (Mean $=2.69)$.

Evaluations of tourist satisfaction: Finally, the service quality score was calculated using the formula proposed by Parasuraman et al. (1988) and Wright (1986): Service Quality Score $=$ Experience ScoreExpectation Score. To enable this calculation, a paired t-test was carried out on the 27 items. The analysis was done at the $5 \%$ level of significance, where $p<0.05$ and $\mathrm{p}<0.01$ were considered significant and highly significant, respectively. Table 2 shows the results for each dimension and item.
Table 2 shows that, in general, the mean score of the respondents' experiences is 2.96 (standard deviation $=0.08)$ compared to a mean score of 3.13 (standard deviation of 0.07 ) for their expectations. This gives a gap of -0.17 , which means that the service quality is low in the sense that the tourists' expectation is higher than their experiences themselves. Specifically, the results in Table 2 show that in all six dimensions used in the study (sustainability, tangibility, reliability, responsiveness, assurance and empathy), the scores for service quality are negative, indicating that the tourist's expectation supersedes their experience(s). The results show that the service quality that the tourists received during their stay in Lake Kenyir was poor, leading to the condition whereby the tourists had become dissatisfied. 
Am. J. Applied Sci., 9 (3): 417-424, 2012

Table 3: The regression results of tourist satisfaction of ecotourism resorts based on factor scores

\begin{tabular}{lllll}
\hline Organizational culture & Independent variable & Sig & Beta, b & $\mathrm{R}^{2}$ \\
\hline Organizational value & Performance orientation & 0.206 & 0.234 & 0.0324 \\
& Employees' characteristics & 0.605 & 0.084 & 0.0053 \\
Organizational practice & Resort characteristics & 0.558 & 0.094 & 0.0069 \\
& Environmental friendly practice & 0.042 & 0.344 & 0.0870 \\
& Pragmatic Vs. normative & 0.435 & 0.130 & 0.0123 \\
& Ecotourism traits & 0.306 & 0.162 & 0.0210 \\
\hline
\end{tabular}

Pearson product-moment correlation: The relationship between resort performance (tourist satisfaction) and organizational culture (value and practice) was investigated using the Pearson productmoment correlation coefficient, as it fulfills the conditions associated with this parametric technique. Pearson's coefficient ( $r$ ) measures the strength and direction of a linear relationship between two variables (Ahlgren et al., 2003). The coefficient (r) can only take on values from -1 to +1 in which the sign indicates whether there is a positive correlation between the variables (as one variable increases, so does the other) or a negative correlation between them (as one variable increases, the other decreases) (Ahlgren et al., 2003). Cohen (1988) suggests the following guidelines for interpreting the coefficient: $r= \pm 0.10$ to \pm 0.29 is small, $r= \pm 0.30$ to \pm 0.49 is medium and $r= \pm 0.50$ to \pm 1.0 is large. Table 3 shows the results.

The result shows that the Sig. value for Environmental Friendly Practice is 0.042 (less than 0.05 (Pallant, 2011) which means that the variable is making a significantly unique contribution to the prediction of the dependent variable (Tourist Satisfaction). The largest beta value is the Environmental friendly practice with 0.344 . This means that this variable makes the strongest unique contribution towards explaining the Tourist Satisfaction. The $\mathrm{R}^{2}$ value for Environmental Friendly Practice is 0.0870 , further indicating that this variable explains $8 \%$ of the variance in Tourist Satisfaction. Therefore, environmental friendly practices ranging from the issue of recycling, being compatible with local environment and culture and making minimal changes to the existing landform, should be the focal points of the strategic policy in the future, in order to improve the planning and management of the resorts and the area promoted for tourism.

\section{CONCLUSION}

The findings of this study make unique contribution to our understanding of organizational culture and their implications for ecotourism performance with respect to tourist satisfaction. The study indicates that tourists are dissatisfied and one aspect of organizational culture; that is the environmental practices construct, is positively correlated with tourist satisfaction. Thus, the specific area which will significantly increase tourist satisfaction level lies in terms of environmental friendly practices. In order to improve performance in terms of tourist satisfaction, resort managers should exert more efforts in adopting environmental friendly practices.

In this research, performance is measured using only tourist satisfaction as resort performance indicators. However, many other performance indicators can also be used in the future. Different inputs might create different results that might be positively correlated with culture. Also, there might be more dimensions of organizational culture to consider than those used by Hofstede and House. Future research on cross-organizational culture will be improved if other cultural values and practices can be identified. The validity of the research findings is somewhat limited, due to the inadequate number of resorts and respondents involved in this study.

Future research should also work to improve the research (tourist satisfaction) model to consider one which is less biased and easier to carry out as opposed to the before-after data collection inherent in the SERVQUAL model. Future research should extend the scope by covering more lake-based resorts with more respondents, so as to allow rigorous statistical analysis to be able to be conducted.

\section{ACKNOWLEDGMENT}

The researchers acknowledge the support of Universiti Sains Malaysia for the Research University Grant entitled 'Tourism Planning' [Grant No. 1001/PTS/8660013] which made this study possible.

\section{REFERENCES}

Ahlgren, P., B. Jarneving and R. Rousseau, 2003. Requirements for a cocitation similarity measure, with special reference to Pearson's correlation coefficient. J. Am. Soc. Inform. Sci. Technol., 54: 550-560. DOI: 10.1002/asi.10242 
Ahmad, A.P., M. Shabanifard, A. Hosseini and O. Soltanipour, 2010. Study of tourists' rights in iran with emphasis on urban tourist rights. J. Soc. Sci., 6: 340-349. DOI: 10.3844/jssp.2010.340.349

Akama, J.S. and D.M. Kieti, 2003. Measuring tourist satisfaction with Kenya's wildlife safari: A case study of Tsavo West National Park. Tourism Manage., 24: 73-81. DOI: 10.1016/S02615177(02)00044-4

Alegre, J. and M. Cladera, 2006. Repeat visitation in mature sun and sand holiday destinations. J. Travel Res., $\quad 44$ : 288-297. DOI: 10.1177/0047287505279005

Alston, A.J. and W.W. Miller, 2001. Analyzing the barriers and benefits toward instructional technology instruction in north carolina and virginia secondary agricultural education curricula. J. Southern Agric. Educ. Res., 51: 50 -62.

Arabatzis, G. and E. Grigoroudis, 2010. Visitors' satisfaction, perceptions and gap analysis: The case of Dadia-Lefkimi-Souflion National Park. Forest Policy Econ., 12: 163-172. DOI: 10.1016/j.forpol.2009.09.008

Blake, R.R. and J.S. Mouton, 1964. The Managerial Grid: Key Orientations for Achieving Production Through People. 1st Edn., Gulf Publishing Company, Houston, Tex., ISBN: 0872014746, pp: 340.

Brebbia, C.A. and F.D. Pineda, 2010. Sustainable Tourism IV. 1st Edn., WIT Press, UK., ISBN: 1845644581, pp: 592.

Chand, M. and A.A. Katou, 2007. The impact of HRM practices on organisational performance in the Indian hotel industry. Employee Relat., 29: 576594. DOI: $10.1108 / 01425450710826096$

Chegini, M.G., 2010. The relationship between organizational culture and staff productivity public organizations J. Soc. Sci., 6: 127-129. DOI: 10.3844/jssp.2010.127.129

Chui, C.T.B., 2010. Segmenting nature-based tourists and perception of services cape at Taman Negara (National Park Malaysia). Proceedings of 2010 International Conference on Business, Economics and Tourism Management, (BETM' 10), World Academic Press, Singapore.

Cohen, J., 1988. Statistical Power Analysis for the Behavioral Sciences. 2nd Edn., Routledge, ISBN: 0805802835 , pp: 567.

Dennison, D.R., 1984. Bringing Corporate Culture to the Bottom Line. 1st Edn., Periodicals Division, American Management Associations, New York, pp: 22 .
Dinan, C., P. Student and A. Sargeant, 2000. Social marketing and sustainable tourism-is there a match? Int. J. Tourism Res., 2: 1-14. DOI: 10.1002/(SICI)1522-1970(200001/02)2:1<1::AIDJTR178>3.0.CO;2-5

Eraqi, M.I., 2006. Tourism services quality (TourServQual) in Egypt: The viewpoints of external and internal customers. Benchmark.: Int. J., 13: 469-492. DOI: $10.1108 / 14635770610676308$

Erdogan, N. and C. Tosun, 2009. Environmental performance of tourism accommodations in the protected areas: Case of goreme historical national park. Int. J. Hospitality Manage., 28: 406-414. DOI: $10.1016 /$ j.ijhm.2009.01.005

Franco, M. and M. Bourne, 2003. Factors that play a role in "managing through measures". Manage. Decision, 41: 698-710. DOI: 10.1108/00251740310496215

Garcia-Falcon, J.M. and D. Medina-Munoz, 1999. Sustainable tourism development in islands: A case study of Gran Canaria. Bus. Strategy Environ., 8: 336-357. DOI: 10.1002/(SICI)10990836(199911/12)8:6<336::AIDBSE217>3.0.CO;2-7

Gardner, R.L., 1999. Benchmarking organizational culture: Organizational culture as a primary factor in safety performance. Professional Safety, 44: 2632.

He, G., X. Chen, W. Liu, S. Bearer and S. Zhou et al., 2008. Distribution of economic benefits from ecotourism: A case study of wolong nature reserve for giant pandas in China. Environ. Manage., 42: 1017-1025. DOI: 10.1007/s00267-008-9214-3

Hofstede, G. and M.H. Bond, 1984. Hofstede's culture dimensions: An independent validation using Rokeach's value survey. J. Cross-Cultural Psychol., 15: 417-433. DOI: 10.1177/0022002184015004003

Hofstede, G., 1998. Masculinity and Femininity: The Taboo Dimension of National Cultures. 1st Edn., Sage Publications, London, ISBN: 076191028X, pp: 238.

Hofstede, G.H., 2003. Culture's Consequences: Comparing Values, Behaviors, Institutions and Organizations Across Nations. 3rd Edn., Sage Publications, Thousand Oaks Calif., ISBN: 0803973241, pp: 596.

Hofstede, G., G.H. Hofstede and G.J. Hofstede, 2005. Cultures and Organizations: Software of the Mind. 2nd Edn., McGraw-Hill, New York, ISBN: 0071439595, pp: 434. 
House, R.J., 2004. Culture, Leadership and Organizations: The GLOBE Study of 62 Societies. 1st Edn., Sage Publications, Thousand Oaks Calif., ISBN: 0761924019, pp: 818.

Jamil, M.F.C., N.A. Yusof, I Said and Z. OSman, 2010. Organizational culture and performance of resort operators of a lake-based tourism area in Malaysia. World Applied Sci. J., 10: 597-606.

Khan, M., 2003. ECOSERV: Ecotourists' quality expectations. Annals Tourism Res., 30: 109-124. DOI: 10.1016/S0160-7383(02)00032-4

Kozak, M., 2001. Repeaters' behavior at two distinct destinations. Annals Tourism Res., 28: 784-807. DOI: 10.1016/S0160-7383(00)00078-5

Kyriakidou, O. and J. Gore, 2005. Learning by example: Benchmarking organizational culture in hospitality, tourism and leisure SMEs. Benchmark.: Int. J., 12: 192-206. DOI: 10.1108/14635770510600320

Martins, E.C. and F. Terblanche, 2003. Building organisational culture that stimulates creativity and innovation. Eur. J. Innov. Manage., 6: 64-74. DOI: 10.1108/14601060310456337

Nejad, S.A.H.S. and G.A. Tularam, 2010. Modeling tourist arrivals in destination countries: An application to australian tourism. J. Math. Stat., 6: 431-441. DOI: 10.3844/jmssp.2010.431.441

Pallant, J., 2011. SPSS Survival Manual: A Step by Step Guide to Data Analysis using the SPSS Program. 4th Edn., Allen and Unwin, Crown Nest, New South Wales, ISBN: 1742373925, pp: 345.

Parasuraman, A., V.A. Zeithaml and L.L. Berry, 1988. SERVQUAL: A multiple-item scale for measuring consumer perceptions of service quality. J. Retail., 64: 12-40. DOI: 10.1016/S0148-2963(99)00084-3

Petrosillo, I., G. Zurlini, M.E. Corliano, N. Zaccarelli and M. Dadamo, 2007. Tourist perception of recreational environment and management in a marine protected area. Landscape Urban Plann., 79: 29-37. DOI: 10.1016/j.landurbplan.2006.02.017
Philips, P. and P. Louvieris, 2005. Performance measurement systems in tourism, hospitality and leisure small medium-sized enterprises: A balanced scorecard perspective. J. Travel Res., 44: 201-211. DOI: $10.1177 / 0047287505278992$

Sathe, V., 1985. Culture and Related Corporate Realities: Text, Cases and Readings on Organizational Entry, Establishment and Change. 1st Edn., R.D. Irwin, Homewood, IL., ISBN: 0256031428, pp: 579.

Schein, E.H., 1990. Organizational culture. Am. Psychol., 45: 109-119. DOI: 10.1037/0003066X.45.2.109

Seth, N., S.G. Deshmukh and P. Vrat, 2005. Service quality models: A review. Int. J. Qual. Reliab. Manage., 22: 913-949. DOI: $10.1108 / 02656710510625211$

Vargas-Hernandez, J.G. and M.R. Noruzi, 2009. An exploration of the organizational culture in the international business relationships and conflicts Era. Am. J. Econ. Bus. Admin., 1: 182-193. DOI: 10.3844/ajebasp.2009.182.193

Williams, A., P. Dobson and M. Walters, 1993. Changing Culture: New Organizational Approaches. 2nd Edn., Institute of Personnel Management, London, ISBN: 0852925336, pp: 309.

Wright, P., 1986. A cultural audit: First step in a needs analysis?? J. Eur. Indus. Train., 10: 28-31. DOI: $10.1108 / \mathrm{eb} 002194$

Yusof, N.A. and M.W.M. Shafiei, 2011. Factors affecting housing developers' readiness to adopt innovative systems. Housing Stud., 26: 369-384. DOI: $10.1080 / 02673037.2011 .542097$ 